procured from the Steretary of State of said State a certificate such as he is required by law to issue, certifying that there had been on the $31 \mathrm{st}$ day of December, 1 s95, filed in his Department "an instrument in writing, purporting to be articles of association of a corportion to be known as the Wisconsin Eclectic Medical College ht Milwakee, without capital college, etc., and that, therefore the State of Wisconsin did certify and rant unto the said Wisconsin Eclectic Hedical College th Milwaikee the powers and privileges conferred by Chapter $6 t^{\circ}$ of the Revised Statutes of the State of Wisconsin, and all acts amendatory thereof, for th purposes rbove stated, and in accordance with their said articles of association."

In witness whereof the said Secretary of State alfixed his baud and oflicial seal on the said 31st day of December, 1895 .

Complainant further alleges upon information and belief that thereafter Fred Rutland aud In Neve Rutiand, for the purpose of carrying out their fraudulent scheme as aforesaid, caused a large number of advertisements to be inserted in newspapers throughout this and other Strtes, and a large number of circulars soliciting persons to apply to it for diplornas and licenses such as would permit them to practice medicine and surgery in this and other states, shid advertisements and cir culars among other things stating in substance that if the applicant should be able to answer before a catar ques prescribed by said corporation that said corporation would issue a diploma to such persons which diplom would enable such person to protich of practice medteris of its authority to issue such diploma, and for the purpose of inducing persons to act upon these statements, said Fred Rutlapd and his wife woula send out with such circulars a copy of the certificate issued by circulars that the State of Wisconsin had satisfied itself that the purposes of the corporation were regular and in accordance with the law and had accepted a fee for incorporation and affixed its seal to the charter of said corporation, which charter declared the purposes and methods of the corporation, aud that the State thereby had sanctioned such purposes, and that therefore no person or power could distur either said college or its graduates.

That by means of the authority apparently conferred upon said corporation by its articles of incorporation aud through said advertise ments and said circulars the said fred Rutlaud and wife have induced a great many persous to apply to them for aud to pay them considerable sums of money for such diplomas, and have issued a great mauy of such diplomas to such persons, who have made no preparation or study of either the scieuce of medicine or surgery, and who are wholly unfit and iucompetent to pructice either the science of medicine or surgery.

Complainaut denies that he has any knowledge or information sulficient to form a belief as to how many of such diplomas have been issued. but alleges that a large number of them have been issued, and

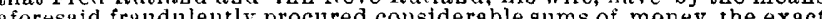
a foresti fruthe inount of what coliet that said Fred kund for euch of suid diplomas a sum varying from to to $\$ 0$, according to the ibility of the apnlicant to pey for the sem. ty of the applicant to pay for the a am

Complainunc alleges upon information and belief that not only was said corpotation organized as aforesuld solely for the purpose 0 described, but that said fraudulent business above described is now and will continue to be its ouly business so loug as said corporation shal ve perunitted to exist.

That the carrying on of said business is detrimental to the advance ment of the science of medicine and surgery, as well as contrary to good morals and public policy. That it directly tends to encourage ignorant, unscrupilous and wholly unfit persons to practice the important professions of medicine and surgery, therebr greatly endaugering the welfare and good health of many of the people of this State.

In thort. that the carrying on of said business by said corporation is clearly a wilful misuse and abuse of the privileges and franchises conferred upou it by its articles of incorporation.

WhEREFore, Complainaut prays the Court that it will vacate the charter aud and the existeuce of the said Wisconsin Eclectic Medica College at Milwankee. toether with such other and further relief as to the Cuturt may seem just and equitable.

\section{Medical Society of State of Pennsylvania.}

Harrisburg, PA., June 15, 1896.

To the Editor:-In your issue of May 30, page 1092, it is stated the "next convention will be held at Pittsburg in September, 1897." The next meeting of the Medical Society of the State of Pennsylvania will be held in Pittsburg, Pa., the third Tuesday of May, 1897. There was some mention of September, but May is provided for in the By-Laws. Convention is not a good word to use for meetings of medical men, though a good many journals use it, our JounN $A$ L should set a better example. The above correction of date and title is so you can have the list of meetings correct. Very truly,

W. T. Bishop, M.D.

\section{The Journal Itself}

New Castle, Ind., June 5, 1896.

To the Editor:- . . . . It is the best medical journal published, the best the Association has ever had, and improv ing weekly.

G. W. Burke, M.D.

Liberty, Mo., June 14, 1896.

To the Editor:-Allow me to compliment the Journal as one of the best in the United States.

J. M. ALLEN, M.D.
Chicago, June 6, 1896.

To the Editor:-In enclosing my vote, I take pleasure in asking to be allowed to thank you for your good work on our Journal. I think it is the high-class weekly for the general profession in the United States. Cordially yours,

Albert B. Hale, M.D.

Clyde, N. Y, June 12, 1896.

To the Editor:-With great pleasure I acknowledge the receipt of my much wished for copy of the Jounnal of Dec. 28,1895 . I am more than ever tenacious that there shall be no break, as, without tiattery, under the present editorial conduct, it is a library of itself, and the best medical journal now published.

I assume to be a competent judge, as I have been a reader of it since its first publication in the weekly form.

$$
\text { Yours truly, D. Colvin, M.D. }
$$

Cincinnati, June 5, 1896.

To the Editor:-I enclose to you my ballot, as also my check for $\$ 5$ for yearly dues.

Now, my dear Doctor, I want to thank you for your distinguished services as Editor of the JournaL. I think it ranks with the journals of the East.

The tone of the Journal is high. It firmly supports the Code. In my opinion, it will grow and grow, and show the world that no section can control the Western and Southern profession. Wishing you and the Journal all success, I am Yours truly, John A. MurPhy, M.D.

\section{PUBLIC HEALTH.}

Dr. Bond of Gloucester, Eng., sends us a copy of a useful leaflet drawn up by him and entitled "Our duty in regard to Vaccination, or fifteen reasons why we should believe in the efficacy of Vaccination as a Preventive of Smallpox." This might be distributed broadcast in those districts where recalcitrant Board of Guardians have failed to do their duty.

Low Sickness-Rate in the German Army.-It is pleasant now and then to put one's finger on a fact that sustains faith in the application of hygienic measures. The General Staff Surgeon of Prussia reports that by the energetic application of hygienic measures-which include vaccination and revaccination-the invaliding among troops has been reduced 42 per cent. since 1868 , and the mortality has been lessened 57 per cent., which means that two thousand men were alive at the end 1895 who would not have been had the former conditions obtained.

Schools and Disease; A Model Preventive System.-.Dr. Leslie McKenzie, the Health Officer for the Borough of Leith, refers in his annual report for 1895 to the system followed in the town for the better prevention of the spread of infectious dis. ease by the agency of 'schools. Each day an official of the School Board of Leith calls upon the health officer for the purpose of receiving lists of infectious cases notified to him, and then proceeds to distribute particulars to the different masters whose schools are interested in the cases, with the view of at once securing the absence from school of all children from an infected house until the house has been declared to be disinfected, etc., to the satisfaction of the health officer or some medical practitioner. Headmasters also notify to the School Board all cases of sickness coming to their knowledge, and thereupon similar steps are taken. The system is modeled on that obtaining at Glasgow, and gives satisfaction. Given the strict carrying out of the plan it ought to succeed.-British Medical Journal.

Annual Death Rate in Peru.--Odriozola's address at the Commencement of the University at Lima, contains the statement that the annual death rate at Peru is from 35 to 40 per thousand, of which a third is due to tuberculosis, while many of 